\title{
a Case Study: Information requirement of paddy growers in Navsari district of South Gujarat
}

ArTiCLE C 26.07.2014;

Accepted :

28.01.2015

\section{KeY WoRdS :}

Information,

Requirement,

Paddy growers
Author for correspondence :

\section{N.M. CHAUAHAN}

Krishi Vigyan Kendra, (N.A.U.), Vyara, TAPI (GUJARAT) INDIA

Email: nikulsinh_m@ yahoo.in

See end of the article for authors' affiliations

\author{
口 VISHVAJEET J. PATEL AND N.M. CHAUAHAN*
}

SUMMARY : The present investigation was confined to Navsari district of South Gujarat. The information need of the 100 rice growers was measured using three point continuums. Major area of information needs expressed by the rice growers, respectively in descending order of rank were schedule of water supply by canal, weed management, marketing, irrigation management, variety, preparation of seedlings, plant protection measures, land preparation and sowing, fertilizer management, harvesting and post harvesting technology and supportive facts. This means that the rice growers gave highest emphasis on schedule of water to be supplied by canal related information, as this information can help them to make a great management on schedule of water to be supplied by canal. They were also conscious about information on weed management as well as marketing and many other aspects of paddy.

How to cite this article : Patel, Vishvajeet J. and Chauhan, N.M. (2015). Information requirement of paddy growers in Navsari district of South Gujarat. Agric. Update, 10(1): 76-80. 